\title{
Effect of Poikilacanthus glandulosus (Nees) Ariza branches and gallic acid against viability of Echinococcus ortleppi protoscoleces
}

\author{
Thiele Faccim de Brum ${ }^{1 *}$, Roberta da Silva Jesus ${ }^{1}$, Bianca Vargas Belke ${ }^{1}$, Danieli Urach Monteiro ${ }^{3}$, Natalia Jank \\ Mossmann ${ }^{2}$, Mariana Piana ${ }^{a}$, Sílvio Terra Stefanello ${ }^{4}$, Félix Alexandre Antunes Soares ${ }^{4}$, Mário Luiz De La Rue ${ }^{3}$ and \\ Liliane de Freitas Bauermann ${ }^{1}$ \\ ${ }^{1}$ Post-Graduate Program in Pharmaceutical Sciences, Federal University of Santa Maria (UFSM). Department of Fisiology and Farmacology, Federal \\ University of Santa Maria, Build 21, Santa Maria, RS 97105-900, Brazil. ${ }^{2}$ Pharmacy Course, Federal University of Santa Maria (UFSM). Department of \\ Pharmacy Industrial, Santa Maria, Brazil. ${ }^{3}$ Post-Graduate Program in Pharmaceutical Sciences,Federal University of Santa Maria (UFSM). Department of \\ Microbiology and Parasitology, Santa Maria, Brazil. ${ }^{4}$ Post-Graduate Program in Biochemical Toxicology, Federal University of Santa Maria (UFSM). \\ Department of Biochemistry and Molecular Biology, Santa Maria, Brazil.
}

\begin{tabular}{|c|c|}
\hline ARTICLE INFO & ABSTRACT \\
\hline $\begin{array}{l}\text { Article history: } \\
\text { Received on: } 12 / 04 / 2016 \\
\text { Accepted on: } 14 / 12 / 2016 \\
\text { Available online: } 30 / 08 / 2017\end{array}$ & $\begin{array}{l}\text { The aim of this study was to assess the antioxidant capacity and to evaluate effect of } P \text {. glandulosus on the } \\
\text { viability of protoscoleces of Echinococcus spp. as well as determine the possible substance in charge for this } \\
\text { action. Echinococcus ortleppi protoscoleces were exposed front of the crude extract and butanol fraction and } \\
\text { gallic acid at different times.Phytochemical study revealed the presence of triterpenoids, steroids, coumarins, }\end{array}$ \\
\hline $\begin{array}{l}\text { Key words: } \\
\text { Acanthaceae; antioxidant; } \\
\text { gallic acid; protoscoleces; } \\
\text { scolicidal agent. }\end{array}$ & $\begin{array}{l}\text { flavonoids content was found in the ethyl acetate }(151.34 \pm 1.71 \mathrm{mg} / \mathrm{g}) \text { and dichlorometane }(123.30 \pm 1.46 \mathrm{mg} / \mathrm{g}) \text {, } \\
\text { respectively. For assays with DPPH the ethyl acetate fraction was highlighted }\left(\mathrm{IC}_{50} 95.48 \pm 0.35 \mu \mathrm{g} / \mathrm{mL}\right) \text { and the } \\
\text { dichlorometane fraction significantly reduced lipid peroxidation (IC } 50135.75 \pm 2.39 \mu \mathrm{g} / \mathrm{mL}) \text { and also the } \\
\text { oxidation of DCFH }(15.6 \mu \mathrm{g} / \mathrm{mL}) \text {. The crude extract, butanol fraction and gallic acid showed scolicidal action of } \\
100 \% \text { at } 15,10 \text { and } 15 \text { minutes, respectively. }\end{array}$ \\
\hline
\end{tabular}

\section{INTRODUCTION}

Poikilacanthus glandulosus (Nees) Ariza belong the family Acanthaceae, is a shrub and is distributed in South and Southeast of Brazil, Paraguay, Argentina and Uruguay, presenting as synonyms Justicia umbrosa, Justicia flexuosa and Poikilacanthus flexuosus (Wasshausen and Smith, 1969; Ariza, 1984; Mabberley, 1997; Wasshausen and Wood, 2004).

The external morphology of Poikilacanthus is very similar to the genus Justicia and many of their species have been described belonging to this. Only from the analysis of pollen

\footnotetext{
* Corresponding Author

E-Mail: thichaim@gmail.com
}

morphology that was possible to maintain Poikilacanthus as a genus the part. Pollen characteristics seem to be the only form of distinction between the two genus (Daniel, 1991, 1998). The plant under study lacks chemical studies, pharmacological, biological, toxicological, phytochemical, etc.

There is only one study in the literature which addresses about the antimicrobial screening through the acetone extract of $P$. glandulosus that showed no inhibition for the tested microorganisms (Barneche et al., 2010). The phytochemical compounds of the plant extracts are the major basis of pharmacological activities of natural products (Oloyede, 2005) whereas flavonoids and polyphenols are antioxidants (Pietta, 1998; Mau et al., 2002) and play significant roles in many processes taking place in living systems. 
The antioxidant activity of phenolic compounds is mainly due to their redox properties, which can play an important role in absorbing and neutralizing free radicals, quenching singlet and triplet oxygen, or decomposing peroxides (Osawa, 1994). Synthetic antioxidants are used in foods to prevent lipid oxidation. However, some studies suggest synthetic antioxidants are harmful to human health (Valentao et al., 2002). Consequently, there is increasing interest in finding naturally occurring alternatives from plants for use in food and medicines.

According to Turrens, (2004) all aerobic organisms are exposed to reactive oxygen species (ROS) generated by their metabolism and so, the redox system plays an important role in the survival of the parasite in the host. Parasitic protozoa not only have to eliminate their endogenous toxic metabolites but they should also cope with the oxidative (or respiratory) burst of the host immune system. In general, antiparasitic drugs, which have the ability to inhibit vital redox reactions or promote oxidative stress in parasites, are considered redox-active antiparasitic drugs (Seeber et al., 2005).

Considering the growing interest and the need for research on medicinal plants, especially those species not yet studied, and the need for the development of new agents in the treatment of several diseases,led to development of this work so there is a greater understanding about the chemical constituents, antioxidant capacity and scolicidal effect of P. glandulosus branches front Echinococcus spp. protoscoleces, as well as determine the possible substance in charge for this action.

\section{MATERIAL AND METHODS Animals}

Male Wistar rats (3.0-3.5 months of age and weighing 270-320 g) were maintained in groups of 3-4 rats per cage. They had continuous access to food and water in a room with controlled temperature $\left(22 \pm 3{ }^{\circ} \mathrm{C}\right)$ and on a 12-h light/dark cycle with lights on at 7:00 am. The animals were maintained in accordance to the guidelines of the Brazilian Association for Laboratory Animal Science (COBEA) (project number 030/2012).

\section{Plant Collection and Extractions}

The branches of $P$. glandulosus were collected in Santiago, RS, Brazil in May of 2012. A voucher specimen is preserved in the herbarium of the Department of Biology at UFSM (SMBD 12.442 and 13.178). Plant material was dried at room temperature and powdered in a knife mill. The branches $(2.061$ $\mathrm{Kg}$ ) were macerated at room temperature with $70 \%$ ethanol for a week with daily shaking; the solvent was renewed several times. After filtration, the hydroalcoholic extract (HE) was evaporated under reduced pressure at a temperature below $40^{\circ} \mathrm{C}$, in order to obtain the aqueous extract (AE); part of this $\mathrm{AE}$ was evaporated to dryness to furnish a crude extract $(\mathrm{CE})$. The remaining $\mathrm{AE}$ was partitioned with solvents of increasing polarity: dichloromethane $\left(\mathrm{CH}_{2} \mathrm{Cl}_{2}-\mathrm{F}\right)$, ethyl acetate (AcOEt-F) and $n$-butanol (BuOH-F). Finally, the fractions obtained were concentrated to dryness on a rotary evaporator. The fractionation method is illustrated in the Figure 1.

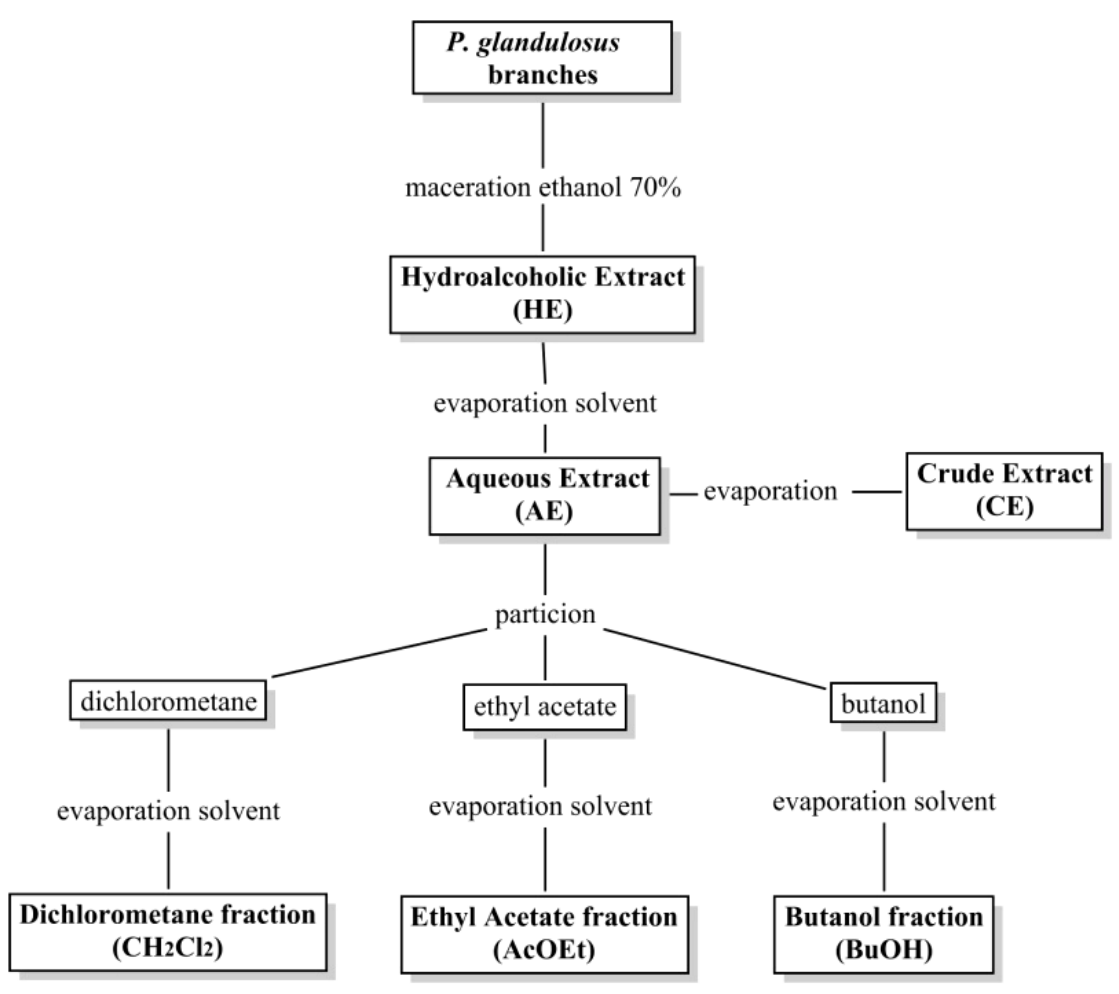

Fig. 1: Method of fractionation of P. glandulosus branches extracts. 
Phytochemical analysis

Qualitative Analysis of Compounds

The phytochemical analysis was realized in according with literature specialized (Moreira, 1979; Matos, 2009), observing the individual methodology for each reaction and verify the possible presence of the chemical groups of secondary metabolism in the plant drug.

\section{Determination of Total Phenolics}

Total phenolic contents were measured using FolinCiocalteu method, slightly modified as described by Chandra et al. (2004). Total phenolic content was expressed in milligrams equivalents of gallic acid (GAE) per gram of each fraction, using GA as standard.

\section{Determination of Total Flavonoids}

Total flavonoids were determined according to the colorimetric method described by Woisky and Salatino (1998), using a $2 \%$ aluminum chloride solution. The flavonoid content was established in milligrams equivalents of rutina (RE) per gram of each fraction, using $\mathrm{R}$ as standard.

\section{HPLC/DAD Analysis of GA}

The CE and fractions of the $P$. glandulosus were analyzed by HPLC performed with a Prominence Auto-Sampler (SIL-20A) equipped with Shimadzu LC-20AT reciprocating pumps connected to a DGU-20A5 degasser and CBM-20A integrator, UV-VIS detector DAD SPD-M20A and LC Solution 1.22 SP1 software. Reversed phase chromatographic analyses were carried out under gradient conditions using a C-18 column (250 $\mathrm{mm} \times 4.6 \mathrm{~mm}$ ). The GA analysis was carried out using a gradient system using Solvent A (water containing $2 \%$ acetic acid) and Solvent B (acetonitrile), according to Boligon et al., (2012). The flow rate was $0.6 \mathrm{~mL} / \mathrm{min}$ and the injection volume was 40 $\mu \mathrm{L}$, with 60 minutes of time duration of analysis. Identification of compounds was performed by comparing retention times and the Diode-Array-UV spectra with those of standards.

\section{Antioxidant Capacity Methods}

\section{DPPH Assay}

The antioxidant capacity of the fractions and the CE was evaluated by monitoring its ability in quenching the stable free radical DPPH, according to Choi et al., (2002). The DPPH quenching ability was expressed as $\mathrm{IC}_{50}$ and a solution of DPPH (1 $\mathrm{mL} ; 0.3 \mathrm{mM})$ in ethanol $(2.5 \mathrm{~mL})$ was used as a negative control and $\mathrm{AA}$ in the same concentrations used for the samples provided the positive control.

\section{TBARS Assay}

TBARS production was determined as described by Ohkawa et al., (1979). Rats were killed and the encephalic tissue was rapidly dissected and placed on ice. Tissues were immediately homogenized in cold 10 mMTris-HCl, pH 7.5 (1/10, w/v). The homogenate was centrifuged for $10 \mathrm{~min}$ at $4,000 \times g$ to yield a pellet that was discarded and a low-speed supernatant (S1). An aliquot of $100 \mu \mathrm{L}$ of S1 was incubated for $1 \mathrm{~h}$ at $37^{\circ} \mathrm{C}$ with freshly prepared $\mathrm{FeSO}_{4}(10 \mu \mathrm{M})$, in the presence of $P$. glandulosus fractions.

\section{DCFH-DA Method}

The substrate DCFH-DA was utilized to measured intracellular formation of reactive oxygen species, according to Myrhe et al. (2003). The supernatant of rat brain homogenate was incubating at $37^{\circ} \mathrm{C}$ with different concentrations of $P$. glandulosus fractions. The fluorescence was measured using $488 \mathrm{~nm}$ for excitation and $520 \mathrm{~nm}$ for emission. ROS levels (expressed as $\mu \mathrm{mol}$ of oxidized 2',7'-dichlorofluorescin (DCF) per mg protein) were calculated by interpolation in a standard curve of oxidized DCF (constructed in parallel), corrected by the content of protein (Lowry et al., 1951). Ethanol was used as negative control.

\section{Effect of CE, BuOH-F and GA on the protoscoleces viability of E. ortleppi}

\section{Biological samples and molecular analysis}

Hydatid cysts in lungs and lives of naturally infected bovine were collected in a slaughterhouse in the central region of RS. The protoscoleces viability was assessed with $0.1 \%$ eosin (Moazeni et al., 2012). The percentage considered suitable for the development of our experimental test was $100 \%$ of viability.

DNA extraction was performed using an aliquot of the liquid containing hydatidprotoscoleces, using a commercial kit (QIAamp tissue) (QIAGEN Inc. Chatsworth, CA) according to the manufacturer's instructions. After extraction it was performed the polymerase chain reaction using a pair of primers (5' TTTTTTGGGCATCCTGAGGTTTAT 3'

5' TAAAGAAAGAACATAATGAAAATG 3')

to amplify a fragment of COX-I gene (Bowles et al., 1992). To detect the pattern of bands, the electrophoresis in $1 \%$ agarose gel was performed, stained with ethidium bromide and visualized under UV light. The samples were submitted to DNA sequencing using a pair of primers (cox I) gene. The similarity of DNA sequencing samples was carried out with using BLAST program (Basic Local Alignment Search Tool).

\section{Scolicidal and viability assay}

In this study, it was used $\mathrm{CE}$ and $\mathrm{BuOH}-\mathrm{F}$ in concentrations of $350 \mathrm{mg} / \mathrm{mL}$ of $P$. glandulosus and GA in 7 $\mathrm{mg} / \mathrm{mL}$. Distilled water was used as dilution vehicle of the agents. In each experiment, $500 \mu \mathrm{L}$ of the solution was placed in a test tube, to which $7 \mu \mathrm{L}$ of protoscolex rich sediment (about 1000 protoscoleces) was added. The contents of the tube was gently mixed, this procedure was repeated in times of 5, 10, 15 and 30 minutes for each concentration tested. At the end of each incubation the upper phase was removed and $500 \mu \mathrm{L}$ of $0,1 \%$ eosin stain was then added to the protoscoleces and mixed gently. After $15 \mathrm{~min}$ of incubation the pellet of protoscoleces was 
examined in microscope optic. The percentages of viability were determined by counting minimum of 700 protoscoleces (Moazeni et al., 2012). The viability was evaluated by the same optical microscope, at different times described, observing motility and eosin staining, performing a count of 500 protoscoleces $(7 \mu \mathrm{L}$ hydatid cyst fluid) each evaluation. The protoscoleces were considered viable, when they presented motility and unstained, and not viable with no motility and stained (Yones et al., 2011; Moazeni et al., 2012).

\section{Statistical Analysis}

The results obtained for DPPH, TBARS, scavenging of ROS, total phenolics and flavonoids assays were analyzed statistically by one-way analysis of variance (ANOVA), followed by Tukey's test using the statistical package SAS (2001). For viability protoscoleces analysis, survival curves were plotted using Kaplan-Meier and differences were analyzed using the chi-square test. The experiments were performed in triplicate and when appropriate $p<0.05, p<0.01$ or $p<0.001$ were considered significant. Data were expressed as mean \pm SD.

\section{RESULTS AND DISCUSSION}

In the present work, was possible verify the presence of the main secondary metabolites (Table 1). Among the secondary metabolites found this phytochemical analysis, the coumarins possess several pharmacological activities, such as antithrombotic, anti-inflammatory, antiviral, antitumor and antioxidant properties (Martín-Aragón et al., 1996).

Table 1: Phytochemical analysis of AE and HE extracts of P. glandulosus branches.

\begin{tabular}{lcc}
\hline Secondary metabolites & AE & HE \\
\hline Heterosides anthocyanic & + & + \\
Heterosides cyanogenic & - & - \\
Amino-groups & + & + \\
Volatile acids & - & - \\
Tannins & - & - \\
Anthocyanins, anthocyanidins and flavonoids & + & + \\
Leucoanthocyanidins and flavones & - & - \\
Flavonols, flavanones, flavanonóis and xanthones & - & - \\
Triterpenes & + & + \\
Catechins & + & + \\
Resins & - & - \\
Heterosides cardiotonics & + & + \\
Phenols with ortho and meta free & + & + \\
Phenols with the position para free & + & + \\
Coumarins & + & + \\
Organic acids & + & + \\
Phenols & + & + \\
\hline
\end{tabular}

+ Presence, - Absence.

The presence of phenols was verified, being reported among many other activities, the antioxidant and antiinflammatory, cardioactive heterosides as the hypotensive (Simões et al., 2010), triterpenoids and steroids have a variety of medicinal properties, highlighting anti-inflammatories, analgesics, cardiovascular and antitumor effects (Niero and Malheiros, 2009). Note that negative results do not necessary imply in his absence, it is possible that the quantity of these are small to be detected. Total polyphenols and flavonoids values are given in Table 2.The highest concentration of polyphenols in the AcOEt-F found in this study was expected, because according to the scheme proposed by CechinelFilho and Yunes (1998) and studies qualitative composition of plant extracts second Canadovic et al. (2008)show that phenolic compounds in general, tend to concentrate in this fraction when working with fractions of different polarities. The findings of this work are higher than studies with species of the genus Justicia, as J. gangetica (16.513 mg/g) (Stewart et al., 2013), J. gendarussa (12.68 mg/g) (Amid et al., 2011) and $J$. pectoralis $(1.18 \mathrm{mg} / \mathrm{g})$ (Lizcano et al., 2010).

Table 2: Total polyphenols and flavonoids for crude extract and fractions of $P$. glandulosus.

\begin{tabular}{ccc}
\hline Extract/fraction & $\begin{array}{c}\text { TP } \pm \text { SD } \\
(\mathbf{m g ~ G A E} / \mathbf{g})\end{array}$ & $\begin{array}{c}\text { TF } \pm \text { SD } \\
(\mathbf{m g} \text { RE/g) }\end{array}$ \\
\hline Crude extract & $90.37 \pm 0.49^{\mathrm{d}}$ & $27.68 \pm 0.85^{\mathrm{c}}$ \\
Dichloromethane & $118.65 \pm 2.34^{\mathrm{c}}$ & $123.30 \pm 1.46^{\mathrm{a}}$ \\
Ethyl acetate & $151.34 \pm 1.71^{\mathrm{a}}$ & $51.02 \pm 1.53^{\mathrm{b}}$ \\
Butanolic & $136.98 \pm 1.30^{\mathrm{b}}$ & $27.28 \pm 0.76^{\mathrm{c}}$ \\
\hline
\end{tabular}

Values are expressed as mean \pm standard deviation. ${ }^{\mathrm{a}-\mathrm{d}}$ Means with the different letters in each column are significantly different $(p<0.001)$ according to the Tukey test $(n=3)$.

The $\mathrm{CH} 2 \mathrm{Cl} 2-\mathrm{F}$ showed the highest concentration of flavonoids in a very significantly front the other fractions, following the AcOEt-F. In the extractor solvent, dichloromethane, can be found the methoxylated flavonoids, which can explain the largest content of flavonoids in this fraction (Cechinel Filho and Yunes, 1998), The BuOH-F and CE obtained the lowest values, there being no significant difference between them. In a study conducted by John et al., (2013) with six species of Justicia, they verified the flavonoid content in different parts of the plant, whereas the maximum value was found in the leaves of $J$. betonica (2.86 mg/g). Lizcano and collaborators (2010), reported the flavonoid content of the leaves and stem $J$. pectoralis $(0.75$ and $0.12 \mathrm{mg} / \mathrm{g})$, respectively. These results were lower than those found for all extracts of $P$. glandulosus used in this study for polyphenols and flavonoids. Through HPLC/DAD analysis was verify the presence of GA in all extracts of $P$. glandulosus branches, showing $5.09 \pm 0.12 \mathrm{mg} / \mathrm{g}, 0.68 \pm 0.02 \mathrm{mg} / \mathrm{g}, 2.17 \pm 0.15$ and $6.72 \pm 1.06 \mathrm{mg} / \mathrm{g}$ for $\mathrm{CE}, \mathrm{CH}_{2} \mathrm{Cl}_{2}-\mathrm{F}$, AcOEt-F and $\mathrm{BuOH}-\mathrm{F}$, respectively. According Ferguro and Harris (1999), the antioxidant activity of the phenolic acids is generally determined by the number of hydroxyl groups present in the molecule. Besides the proven antioxidant activity of this compound, preclinical studies have shown that the GA has a variety of pharmacological actions, such as anti-inflammatory, antimicrobial, antiviral and antitumor activities (Kim, 2007; Özçelik et al., 2011). The GA was found by the first time in $P$. glandulosus and others compounds can be investigated, once through this study was observed the significant presence of others peaks in the chromatograms that were not identified.

The DPPH assay is the most common methods to determine antioxidant capacity in a practical, rapid and sensitive manner (Arnao et al., 2000). The best sequestrant capabilities of 
$\mathrm{DPPH}$ in this study were observed in the AcOEt-F $\left(\mathrm{IC}_{50} 95.48\right.$ $\mu \mathrm{g} / \mathrm{mL}$ ), followed by BuOH-F ( $\mathrm{IC}_{50} 118.92 \mu \mathrm{g} / \mathrm{mL}$ ). The $\mathrm{CH}_{2} \mathrm{Cl}_{2}-\mathrm{F}$ and $\mathrm{CE}$ showed weaker antioxidant capacity $\left(\mathrm{IC}_{50} 144.05 \pm 0.23\right.$ and409.5 $\pm 0.76 \mu \mathrm{g} / \mathrm{mL}$ ), respectively (Table 3).

Table 3: Antioxidant capacity for crude extract and fractions of $P$. glandulosus.

\begin{tabular}{ccc}
\hline Extract/fraction & \multicolumn{2}{c}{$\mathbf{I C}_{\mathbf{5 0}} \pm \mathbf{S D}(\boldsymbol{\mu g} / \mathbf{m L})$} \\
\cline { 2 - 3 } & $\mathbf{D P P H}$ & $\mathbf{T B A R S}$ \\
\hline Crude extract & $409.5^{\mathrm{a}} \pm 0.76$ & $\#$ \\
Dichloromethane & $144.05^{\mathrm{b}} \pm 0.23$ & $135,75 \pm 2,39$ \\
Ethyl acetate & $95.48^{\mathrm{d}} \pm 0.35$ & $\#$ \\
Butanolic & $118.92^{\mathrm{c}} \pm 0.28$ & $\#$ \\
Standarts & & - \\
Ascorbic acid & $15,98 \pm 0,42^{\mathrm{e}}$ & $*$ \\
BHT & - &
\end{tabular}

Values are expressed as mean \pm standard deviation. ${ }^{\mathrm{a}-\mathrm{e}}$ Means with the different letters in each column are significantly different $(p<0.05)$ according to the Tukey's test $(\mathrm{n}=3)$. The $\mathrm{IC}_{50}$ value found by linear regression corresponding to a value smaller than the concentrations tested. \# The value of $\mathrm{IC}_{50}$ found by linear regression corresponding to a value higher than the concentrations tested.

The results are in agreement with the content of polyphenols found in the fractions, so is possible to attribute the antioxidant capacity seen in the DPPH assay to the presence of these compounds. This positive correlation can be explained on the basis of the similarity between compounds with high antioxidant activity extracted by these organic solvents (Silva et al., 2006; Schubert et al., 2007).

The $\mathrm{CH}_{2} \mathrm{Cl}_{2}-\mathrm{F}$ showed highest antioxidant capacity, it may be suggested by the high flavonoid content found for this fraction. Our results show that P. glandulosus was more potent in sequestering the DPPH radical when compared with $J$. gendarussa $\left(\mathrm{IC}_{50} 482.5 \mu \mathrm{g} / \mathrm{mL}\right.$ ) (Krishma et al., 2010) and J. spicigera $\left(\mathrm{IC}_{50}\right.$ of $944.67 \mu \mathrm{g} / \mathrm{mL}$ ) (Sepúlveda-Jiménez et al., 2009). For the TBARS analysis, the $\mathrm{CH}_{2} \mathrm{Cl}_{2}$-Fwas the one that presented significant reduction in lipid peroxidation compared to baseline, from the concentration of $31.2 \mu \mathrm{g} / \mathrm{mL}$ and $\mathrm{IC}_{50}$ of $135.75 \mu \mathrm{g} / \mathrm{mL}$ (Table 3 and Figure 2). However, this correlation was not possible to check with other fractions that showed values polyphenols and flavonoids relatively high. By linear regression analysis, was possible to perceive that the other fractions were not capable of reducing the lipid peroxidation, requiring largest concentrations, which may produce a toxic effect.

There are several methods to analyze the antioxidant capacity, mainly because there are different mechanisms that plant extracts can exert this action. The fluorogenic compound DCFHDA has been utilized extensively as a marker for oxidative stress, and is suggested to reflect the overall oxidative status of the cell (Wang and Joseph, 1999).

In this work, the $\mathrm{CH}_{2} \mathrm{Cl}_{2}-\mathrm{F}$ significantly decreased the oxidation of DCFH at a concentration of $15.6 \mu \mathrm{g} / \mathrm{mL}$ (Figure 3). The BuOH-F was able to significantly reduce levels of oxidation of DCFH from the concentration of $125 \mu \mathrm{g} / \mathrm{mL}$ and the AcOEt-F, only in the most concentration tested $(250 \mu \mathrm{g} / \mathrm{mL})$. The CE was not able to reduce significantly the oxidation of DCFH. The results of this study suggest that $P$. glandulosus was able to reduce the levels of malondialdehyde and also the basal ROS generation in rat brains, especially $\mathrm{CH}_{2} \mathrm{Cl}_{2}-\mathrm{F}$.

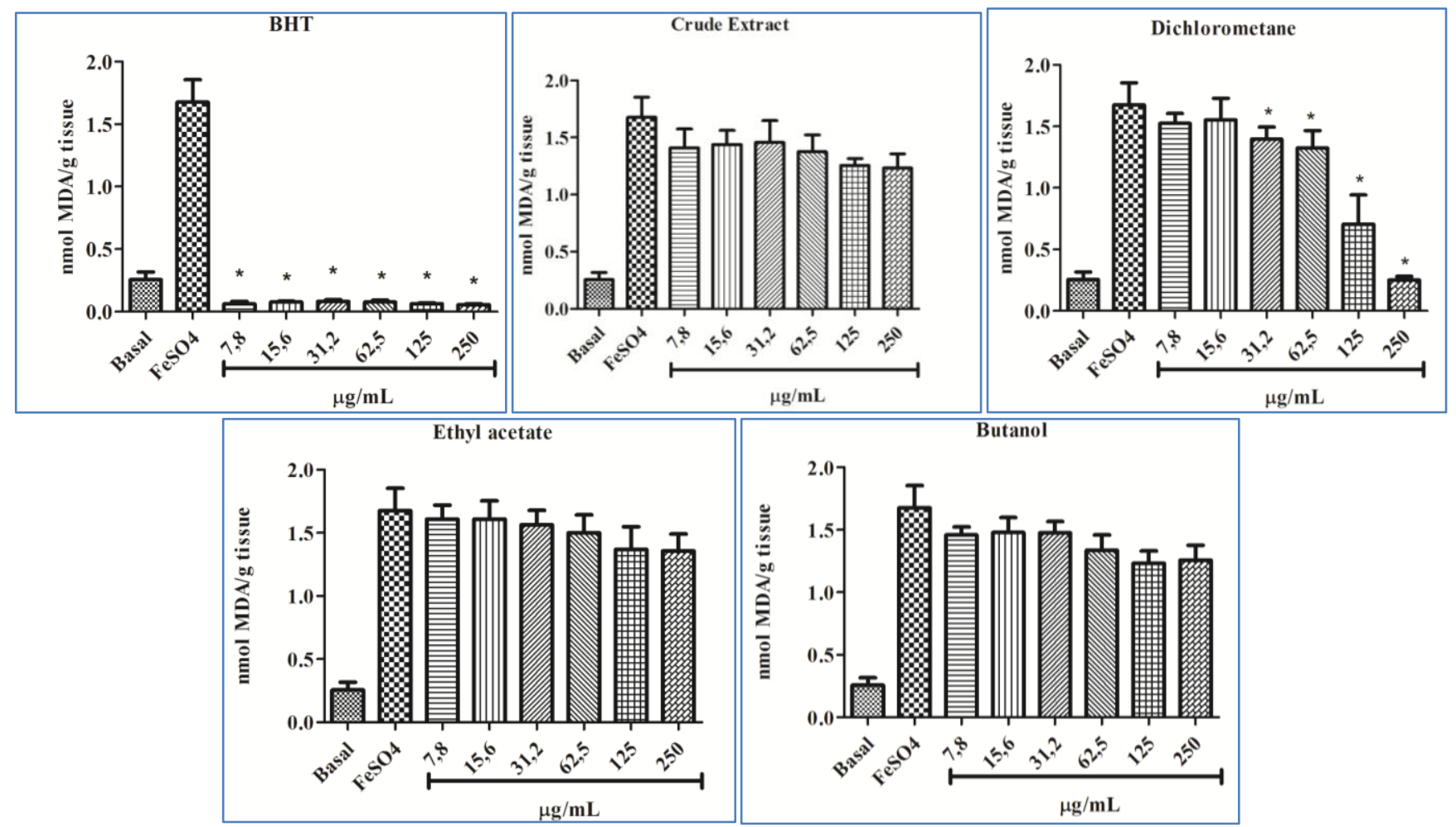

Fig. 2: Effect of different concentrations fractions from the branches of $P$. glandulosus on Fe(II) $(10 \mu \mathrm{M})$-induced TBARS production in brain homogenates. Dates are expressed as means \pm S.D., $(n=3)$. Significant differences are indicated by * $\mathrm{p} \leq 0.05$ when compared with $\mathrm{FeSO}_{4}$ group. 
Echinococcosis is a zoonotic infection caused by cestode species of the genus Echinococcus. This neglected disease is distributed worldwide and causes illnesses in humans and animals (Cardona and Carmena, 2013). Echinococcus ortleppi is found in southern Brazil (Balbinotti et al., 2012) and in determined parts of Europe, Africa, South Asia and the Americas (Dinkel et al., 2004). There are also reports of E. ortleppi causing cystic echinococcosis in humans (Maravilla et al., 2004; Sharma et al., 2013). To date, many scolicidal agents have been used for inactivation of the hydatid cyst content, but there is no ideal agent that is both effective and safe. An ideal scolicidal agent is define as being potent in low concentrations, acting in a short period time, being stable in cyst fluid, not affected by dilution with the cyst fluid, being able to kill the protoscoleces in the cyst, being non-toxic, having low viscosity, and being readily available and easily prepared, as well as being inexpensive (Moazeni and Nazer, 2010). The mainstay of treatment for hydatid disease is surgery. Surgical approaches depend on the parasitized organ and cyst size. In order to prevent recurrence of secondary hydatid cysts, inactivation of protoscoleces with scolicidal agents before the cyst removal is recommended. As it is also indicated the use of powerful scolicidal the alternative method of treatment puncture, aspiration, injection and recirculation(Park et al., 2009). For this study, the protoscoleces were identified molecularly as the specie E. ortleppi. GA was found in all fractions of P. glandulosus, but in larger quantities in the $\mathrm{CE}$ and $\mathrm{BuOH}-\mathrm{F}$, which ledus toconduct this studywith the standardand theseextracts in an attempt tojustifythis activity. The effect of $P$. glandulosus front $E$. ortleppi protoscoleces revealed that $\mathrm{CE}$ and $\mathrm{BuOH}-\mathrm{F}$ at concentration of $350 \mathrm{mg} / \mathrm{mL}$ can kill all protoscoleces acting in a short period time (10 at 15 minutes of application, respectively). The GA was able to kill all protoscoleces in 15 minutes of exposure at concentration $7 \mathrm{mg} / \mathrm{mL}$ (Figure 4).

This significant effect of $P$. glandulosus extracts can be explained by good activity of GA standard that was identified by HPLC-DAD analysis in this specie. The GA has a variety of pharmacological actions, but as far as we know, this is the first report on the scolicidal activity this compound. The relation between antiparasitic and antioxidant activities of natural compounds have long been under investigation and discussed, especially on the generation of ROS, but remains unclear (Ribeiro et al., 1997; Moazeni et al., 2012).

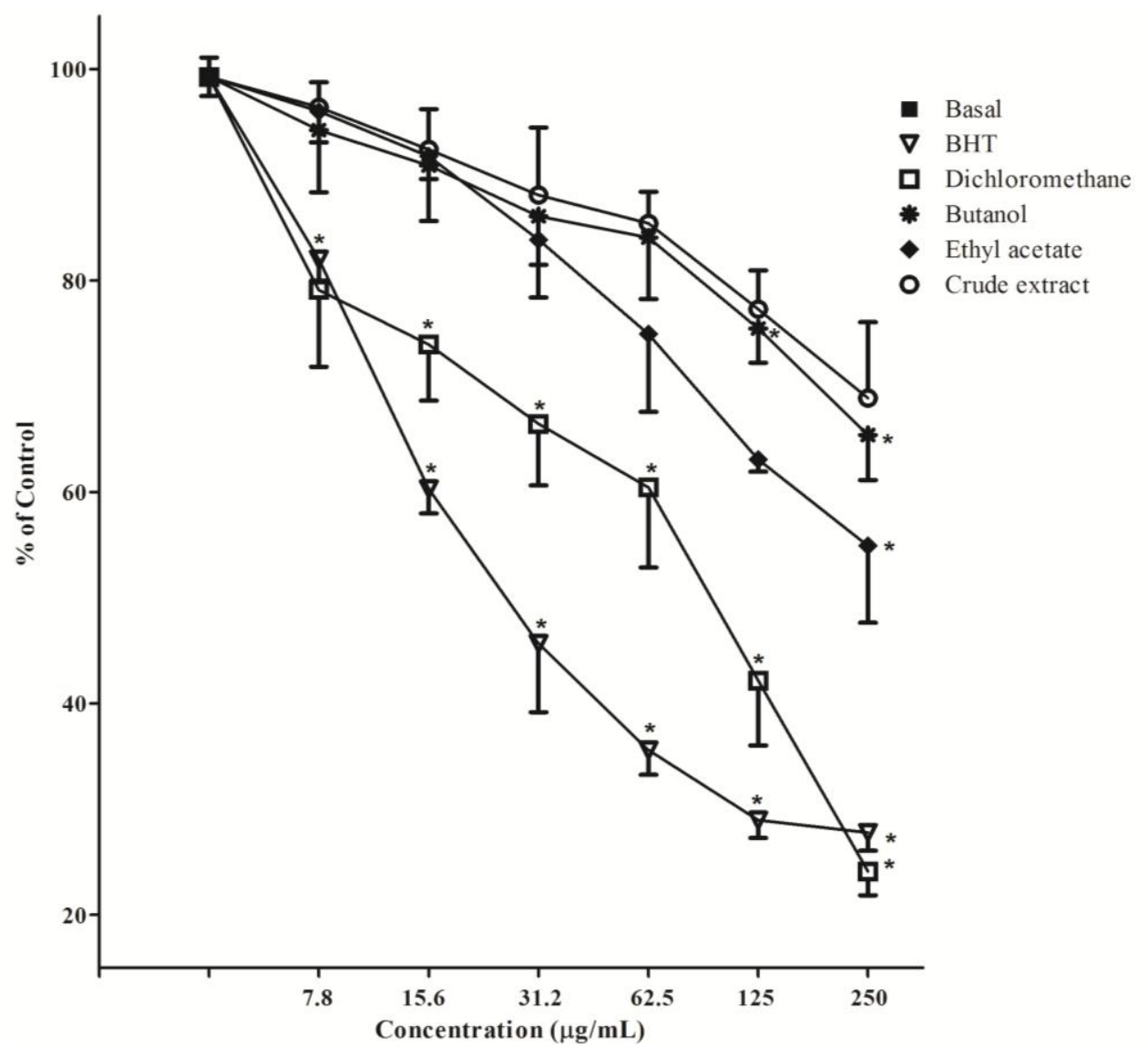

Fig. 3: Effect of the crude extract and fractions of the branches from P. glandulosus on scavenging of ROS in rat brain cells, by DCFH-DA method.

$*$ Data are expressed as means \pm S.D., $(\mathrm{n}=3)$. *Significant difference from the basal group $(p<0.05)$. 


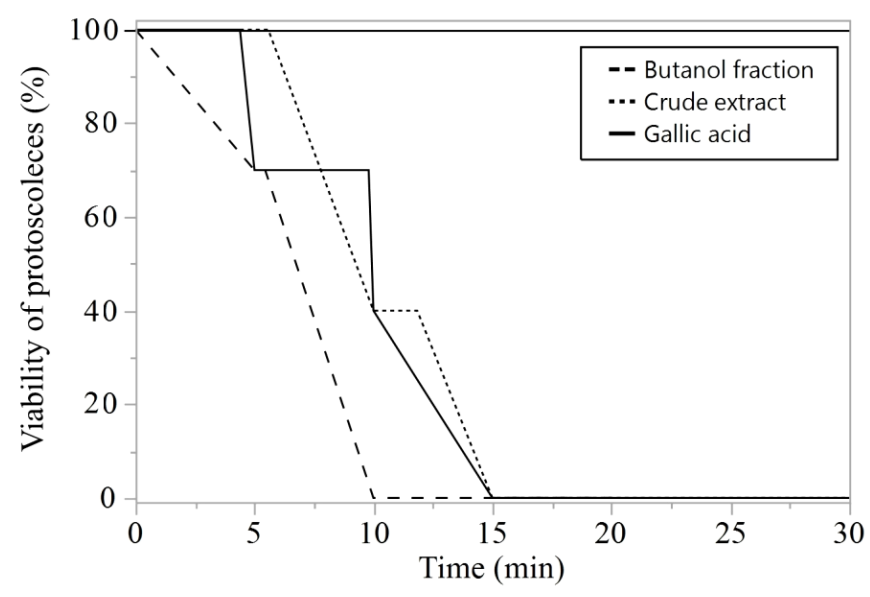

Fig. 4: In vitro effects on the viability of protoscoleces when submitted to $\mathrm{CE}$ $350 \mathrm{mg} / \mathrm{mL}, \mathrm{BuOH}$ fraction $350 \mathrm{mg} / \mathrm{mL}$ of $P$. glandulosus and $\mathrm{GA} 7 \mathrm{mg} / \mathrm{mL}$ in different exposure times.

\section{CONCLUSION}

This study showed the antioxidant activity of $\mathrm{P}$. glandulosus branches by different methods, the scolicidal effect and contributed to reveal some phytochemical compounds of this species for the first time. Taking into account that natural substances can be responsible for the protective effect against the risk of many disease processes, our results suggest that $P$. glandulosus has antioxidant potential and can be a promising source of natural antioxidants. Furthermore, was possible described the significant potential in vitro scolicidal activity of $\mathrm{CE}$ and $\mathrm{BuOH}-\mathrm{F}$ of $P$. glandulosus front the protoscoleces of $E$. ortleppi. The results of this study allowed us to suggest that GA can be the responsible in part by scolicidal effect of $P$. glandulosus, for the reasons cited above. The present study open the possibility of more investigations of in vivo scolicidal effect of this traditional medicine.

\section{ACKNOWLEDGMENTS}

The authors would like to thank Prof. Dr. Margareth Linde Athayde for orientation and support for this work, Prof. Dr. Renato Aquino Záchia for the identification of Poikilacanthus glandulosus, Dr. Carolina Bremm for statistical analysis.

Financial support and sponsorship: Authors are grateful for the financial support provided by FAPERGS (Fundação de Amparo à Pesquisa do Estado do Rio Grande do Sul)/Brazil.

Conflict of Interests: There are no conflicts of interest.

\section{REFERENCES}

Amid A, Johan NN, Jamal P, Zain WNW Mohd. Observation of antioxidant activity of leaves, callus and suspension culture of Justicia gendarusa. Afr J Biotechnol, 2011; 10:18653-18656.

Ariza LE. Notas sobre Acanthaceae. El Genero Poikilacanthus II. Kurtziana,1984; 17: 157-161.

Arnao MB, Cano A, Acosta M.A method to measure antioxidant activity in organic media: application to lipophilic vitamins. Redox Rep, 2000; 5:365-370.
Balbinotti H, Santos GB, Badaraco J, Arend AC, Graichen DAS, Haag KL, Zaha A. Echinococcus ortleppi (G5) and Echinococcus granulosus sensustricto (G1) loads in cattle from Southern Brazil. Vet Parasitol, 2012; 188: 255-260.

Barneche S, Bertucci A, Haretche F, Olivaro C, Cerdeiras MP,Vázquez A. Prospecciónquímica y microbiológica del bosque de galeria del río Uruguay. Braz J Pharmcog, 2010; 20: 878-885.

Boligon AA, Brum TF, Frohlich JK, Froeder ALF, Athayde ML. HPLC/DAD profile and determination of total phenolics, flavonoids, tannins and alkaloids contents of Scutia buxifolia Reissek stem bark. Res J Phytochem, 2012; 3:84-91.

Bowles J, Blair D, Mcmanus DP. Genetic variants within the genus Echinococcus identified by mitochondrial DNA sequencing. Mol Biochem Parasitol, 1992; 54: 165-174.

Canadovic BJ, Cetkovic G, Dilas S, Tumbas V, Bogdanovic G, Mandic A, Markov S, Cvetkovic D, Canadanovic V. Radical scavenging, antibacterial, and antiproliferative activities of Melissa oficinalis L. extracts. J Med Food, 2008; 11: 133-143.

Cardona GA, Carmena D.A review of the global prevalence, molecular epidemiology and economics of cystic echinococcosis in production animals. Vet Parasitol, 2013; 192: 10-32.

Cechinel FV, Yunes RA. Estratégias para a obtenção de compostos farmacologicamente ativos a partir de plantas medicinais. Conceitos sobre modificação estrutural para otimização da atividade. Quím Nova, 1998; 21: 99-105.

Chandra S, Mejia EG. Polyphenolic compounds, antioxidant capacity and quinonereductase activity of an aqueous extract of Ardisiacompressa in comparision to Mate (Ilex paraguaiensis) and Green (Camellia sinensis) Teas. J Agric Food Chem, 2004; 52: 3583-3589.

Choi CW, Kim SC, Hwang SS, Choi BK, Ahn HJ, Lee MY, Park SH, Kim SK. Antioxidant activity and free radical scavenging capacity between Korean medicinal plants and flavonoids by assay-guided comparison. Plant Sci, 2002; 163: 1161-1168.

Daniel TF.A synopsis of Poikilacanthus (Acanthaceae) in Mexico. Bull Torrey Bot Club,1991; 118: 451-458.

Daniel TF. Pollen Morphology of Mexican Acanthaceae: diversity and systematic significance. Proceedings of the California Academy of Sciences, 1998; 50: 217-256.

Dinkel A, Njoroge EM, Zimmermann A, Wälz M, Zeyhle E, Elmahdi IE, Mackenstedt U, Romig T. A PCR system for detection of species and genotypes of the Echinococcus granulosus - complex, with reference to the epidemiological situation in eastern Africa. Int J Parasitol, 2004; 34: 645-653.

Ferguro LR, Harris PJ. Protection against cancer by wheat bran: role of dietary fibre and phytochemicals. Eur Cancer Prev Org,1999; 8: $17-25$.

John B, Reddy VRK, Sulaiman CT. Total Phenolics and Flavonoids in Selected Justicia Species. J Pharmacog Phytochem, 2013; 2: 72-73.

Kim, Y.J. Antimelanogenic and antioxidant properties of gallic acid. Biol Pharm Bull, 2007; 6: 1052-5.

Krishma KL, Mruthunjaya K, Patel JA. Antioxidant and hepatoprotective potential of stem methanolic extract of Justicia gendarussa Burn. Int J Pharm, 2010; 2: 72-80.

Lizcano LJ, Bakkali MF, Ruiz-Larrea B, Ruiz-Sanz JI. Antioxidant activity and polyphenol content of aqueous extracts from Colombian Amazonian plants with medicinal use. Food Chem,2010; 119: $1566-1570$.

Lowry OH, Rosebrough NJ, Farr AL, Randall RJ. 1951. Protein measurement with the Folin phenol reagent. J BiolChem, 1951; 193: 265275.

Mabberley DJ.1997.The plant book, 2ndedition. Cambridge: Cambridge University Press, 520-521.

Maravilla P, Thompson RCA, Palacios-Ruiz JA, Estcourt A, Ramirez-Solis E, Mondragon-de-la-Peña C, Moller-Moreno M, CardenasMejia A, Mata-Miranda P, Aguirre-Alcantara MT, Bonilla-Rodriguez C, Flisser A. Echinococcus granulosus cattle strain identification in an autochthonous case of cystic echinococcosis in central Mexico. Acta Trop, 2004; 92: 231-236. 
Martín-Aragón S, Benedí J, Villar A. Oxygen active speciesscavenger properties of coumarins. Phytother Res, 1996; 10: S75-S78.

Matos, FJA. Introdução a fitoquímica experimental. 3 Ed. Fortaleza: Editora daUniversidade Federal do Ceará - UFC, p. 20, 2009.

Mau JL, Lin HC, Chen CC. Antioxidant properties of several medicinal mushrooms.JAgric Food Chem, 2002; 50: 6072-6077.

Moazeni M, Nazer A.In vitro effectiveness of garlic (Allium sativum) extract on scolices of hydatid cyst. World JPlastSurg, 2010; 34: 2677-2681.

MoazeniM, Saharkhiz MJ, Hoseini AA, Alavi AM. In vitroscolicidal effect of Satureja khuzistanica (Jamzad) essential oil. AsianPac J TropBiomed,2012; 8: 616-620.

Moreira EA. Contribuição para o estudo fitoquímico de LobeliahassleriA. ZAHLB e LobeliastellfeldiiR. Braga. Companulaceae. Tribuna Farm, 1979; 47: 13-39.

Myrhe O, Andersen JM, Aarnes H, Fonnum F.Evaluation of the probes $2^{\prime}, 7^{\prime}$-dichlorofluorescin diacetate, luminol, and lucigenin as indicators of reactive species formation. BiochemPharmacol, 2003; 65: $1575-1582$

Niero R, Malheiros A. 2009.Principais aspectos químicos e biológicos de terpenos. In: Yunes, R.A., Filho, C.V (Orgs.). Química de produtos naturais, novos fármacos e a moderna farmacognosia, 2nd edition. Itajaí: Universidade do Vale do Itajaí, 259-278.

Ohkawa $\mathrm{H}$, Ohishi N, Yagi K. Assay for lipid peroxides in animal tissues by thiobarbituric acid reaction. Anal Biochem, 1979; 95: 351-358.

Oloyede OI. Chemical Profile of Unripe Pulp of Carica papaya.J Nutr, 2005; 4: 379-381.

Osawa T. 1994. Novel natural antioxidants for utilization in food and biological systems. In: Uritani I, Garcia VV, Mendoza EM (Eds.). Postharvest biochemistry of plant food-materials in the tropics. Tokyo, Japan: Japan Scientific Societies Press, 241-251.

Özçelik B, Kartal M, Orhan I. Cytotoxicity, antiviral and antimicrobial activities of alkaloids, flavonoids, and phenolic acids.Pharm Biol,2011; 49: 396-402.

Park K, Jung S, Jang HC, Shin J. First Successful Puncture, Aspiration, Injection, and Re-Aspiration of Hydatid Cyst in the Liver Presenting with Anaphylactic Shock in Korea.Yonsei Med J,2009; 5: 717 720.

Pietta PG. 1998. Flavonoids in medicinal plants. In: Rice-Evans CA, Packer L (Eds.), Flavonoids in health and disease. New York: Dekker, 61- 110 .

Ribeiro A, Pilo-Veloso D, RomanhaAJ, Zani CL. Trypanocidal flavonoids from Trixisvauthieri. J Nat Prod, 1997; 60: 836-841.

Schubert A, Pereira DF, Zanin FF, Alves SH, Beck RCR, Athayde ML. Comparison of antioxidant activities and total polyphenolic and methylxanthine contents between the unripe fruit and leaves of Ilex paraguariensis A. St. Hil. Pharmazie, 2007; 62: 876-880.

Sepúlveda-Jiménez G, Reyna-Aquino C, Chaires-Martínez L, Bermúdez-Torres K, Rodríguez-Monroy M. Antioxidant activity and content of phenolic compounds and flavonoids from Justicia spicigera. J BiolSci,2009; 6: 629-632.
Sharma M, Sehgal R, Fomda BA, Malhotra A, Malla N. Molecular Characterization of Echinococcus granulosus Cysts in North Indian Patients: Identification of G1, G3, G5 and G6 Genotypes. PLoSNeglTropDis, 2013; 7: 2262.

Silva DA, Silva TMS, Lins ACS,Costa DA, Cavalcante JMS, Matias WN, Souza MFV, Filho BR. Chemical constituents and antioxidant activity of Sidagalheirensis Ulbr. (Malvaceae). Quim Nova,2006; 29: 1250-1254.

Simões CMO, Schenkel EP, Gosmann G, Mello JCP de, Mentz LA, Petrovick PR. 2010. Farmacognosia: da planta ao medicamento, 6nd edition. Porto Alegre/ Florianópolis: Ed. UFRGS/Ed. UFSC, 229-615.

Seeber F, Aliverti A, Zanetti G. The plant-type ferredoxin$\mathrm{NADP}+$ reductase/ferredoxin redox system as a possible drug target against apicomplexan human parasites. CurrPharm Des, 2005; 11: 3159-3172.

Turrens JF. Oxidative stress and antioxidant defenses: a target for the treatment of diseases caused by parasitic protozoa. Mol AspectsMed,2004; 25: 211-220.

Valentao P, Fernandes E, Carvalho F, Andrade PB, Seabra RM, Bastos ML. Antioxidative properties of cardoon (Cynara cardunculus L.) infusion against superoxide radical, hydroxyl radical and hypochlorus acid. J Agric Food Chem, 2002; 50; 4989-4993.

Wang H, Joseph JA. Quantifying cellular oxidative stress by dichlorofluorescein assay using microplate reader. Free Rad Biol Med, 1999; 27: 612-6.

Wasshausen DC, Smith LB. 1969. Acantáceas. Itajaí, SC: Ed. Herbário Barbosa Rodrigues, Flora Ilustrada Catarinense, 100-117.

Wasshausen DC, Wood JRI. Acanthaceae of Bolivia. Contributions from the US National Herbarium, 2004; 49:1-152.

Woisky RG, Salatino A. Analysis of propolis: some parameters and procedures for chemical quality control. J Apic Res, 1998; 37: 99105.

Yones D, Taher GA, Ibraheim ZZ .In vitro effects of some herbs used in egyptian traditional medicine on viability of protoscolices of hydatid cysts. Korean J Parasitol, 2011; 49: 255-263.

\section{How to cite this article:}

Brum TFD, Jesus RDS, Belke BV, Monteiro DU, Mossmann NJ, Piana M, Stefanello ST, Soares FSAA, Rue MLDLR, Bauermann LDF. Effect of Poikil acanthus glandulosus (Nees) Arizabranches and gallic acid against viability of Echinococcus ortleppi protoscoleces. J App Pharm Sci, 2017; 7 (08): 123-130. 